\title{
Effect of aspherical and yellow tinted intraocular lens on blue-on-yellow perimetry
}

\section{Efeito das lentes intraoculares asféricas e com pigmentação amarela na campimetria azul-amarelo}

\author{
Rodrigo França de Espíndola ${ }^{1}$, Marcony Rodrigues de Santhiago $^{1}$, Newton Kara-Júnior ${ }^{1}$
}

\begin{abstract}
Purpose: To investigate the possible effect of aspherical or yellow tinted intraocular lens (IOL) on contrast sensitivity and blue-on-yellow perimetry.

Methods: This prospective randomized bilateral double-masked clinical study included 52 patients with visually significant bilateral cataracts divided in two groups; 25 patients (50 eyes) received aspherical intraocular lens in one eye and spherical intraocular lens in the fellow eye; and 27 patients (54 eyes) received ultraviolet and blue light filter (yellow tinted) IOL implantation in one eye and acrylic ultraviolet filter IOL in the fellow eye. The primary outcome measures were contrast sensitivity and blue-on-yellow perimetry values (mean deviation [MD] and pattern standard deviation [PSD]) investigated two years after surgery. The results were compared intra-individually.

Results: There was a statistically significant between-group (aspherical and spherical intraocular lens) difference in contrast sensitivity under photopic conditions at 12 cycles per degree and under mesopic conditions at all spatial frequencies. There were no between-group significant differences (yellow tinted and clear intraocular lens) under photopic or mesopic conditions. There was no statistically significant difference between all intraocular lens in MD or PSD.

Conclusion: Contrast sensitivity was better under mesopic conditions with aspherical intraocular lens. Blue-on-yellow perimetry did not appear to be affected by aspherical or yellow tinted intraocular lens. Further studies with a larger sample should be carried out to confirm or not that hypotheses.
\end{abstract}

Keywords: Lenses, intraocular; Cataract extraction; Phacoemulsification; Glaucoma/ diagnosis; Visual field tests/methods; Visual fields; Lens implantation, intraocular; Contrast sensitivity

\section{RESUMO}

Objetivo: Investigar a possibilidade de efeitos na sensibilidade ao contraste e no resulta dos da campimetria azul-amarelo com implante de uma lente intraocular (LIO) asférica ou de pigmentação amarela.

Métodos: Trata-se de um estudo prospectivo, randomizado, duplo-mascarado, envolvendo 52 pacientes portadores de catarata senil bilateral, divididos em dois grupos; 25 pacientes (50 olhos) receberam uma LIO asférica em um olho e uma esférica no olho contralateral; e 27 pacientes (54 olhos) com implante de uma LIO de pigmentação amarela e uma LIO convencional no olho contralateral. O principal resultado do estudo foi a sensibilidade ao contraste e os dados da perimetria azul-amarelo ("mean deviation" [MD] e "pattern standard deviation" [PSD]). Os resultados foram analisados interindividualmente.

Resultados: Houve diferença estatística entre os grupos (lentes asféricas e esféricas) na sensibilidade ao contraste em condições fotópicas (12 ciclos por grau) e em condições mesópicas (todas frequências). Não houve diferença estatística na sensibilidade ao contrasteentre as lentes de pigmentação amarela e convencionais. Não houve diferença estatística nos valores de MD e PSD entre os grupos.

Conclusão: Asensibilidadeao contrastefoimelhorem condições mesópicas com as lentes asféricas. A campimetria azul-amarelo parece não ser influenciada por LIOs asféricas e com pigmentação amarela. Mais estudos com uma amostra maior são necessários para confirmar ou afastar essa hipótese.

Descritores: Lentes intraoculares; Extração de catarata; Facoemulsificação; Glaucomal diagnóstico; Testes de campo visual/métodos; Campos visuais; Implante de lente intraocular; Sensibilidade de contraste

\section{INTRODUCTION}

Short-wavelength automated perimetry (SWAP) or Blue-on-Yellow $(B / Y)$ perimetry has gained fairly wide acceptance as a clinical test since its initial use more than 10 years ago. SWAP uses moderately bright yellow background fields to depress visual sensitivity that is mediated via long and middle-wavelength-sensitive cones. This selective sensitivity reduction allows visual sensitivity mediated via short-wavelengthsensitive cones to be measured in isolation ${ }^{(1)}$.

Previous studies suggest that visual field defects on $B / Y$ perimetry occur before defects on standard automatic white-on-white perimetry (SAP) and exhibit progression in advance of those recorded with whiteon-white perimetry in both chronic open-angle glaucoma and ocular hypertension ${ }^{(2-5)}$. Although, Tafreshi et al., associates compared SAP, Matrix frequency-doubling technology (FDT) perimetry and SWAP and detected no significant differences in their diagnostic performance ${ }^{(6)}$.
Changes in the absorption characteristics of the human lens with age and lens opacity can influence the results of SWAP(7). Others influences in $B / Y$, such as intraocular lenses (IOLs) with ultraviolet filter, was reported in peer review literature ${ }^{(8)}$. Another type of intraocular lens $(\mathrm{IOL})$ with aspherical surface, could modify the visual performance of patients implanted with these IOLs in relation to those implanted with spherical IOLs.

It has been suggested in previous works that aspherical IOLs can improve contrast sensitivity and reduce the patient's perception of halos and glare ${ }^{(9)}$. These theoretical changes can confound the interpretation of the glaucomatous visual field, and it is a great clinical importance to understand the aspherical IOL's effect upon such mode of perimetry.

The purpose of this prospective study was to investigate the possible effects of an aspherical and a blue-light filter (yellow tinted) IOLs on contrast sensitivity and B/Y perimetry measures.
Submitted for publication: March 1, 2012

Accepted for publication: August 27, 2012

Study conducted in Ophthalmology Department of the University of São Paulo, São Paulo, Brazil.

${ }^{1}$ Ophthalmology Department, Universidade de São Paulo (USP), São Paulo, Brazil.
Funding: No specific financial support was available for this study.

Disclosure of potential conflicts of interest: R.F.Espíndola, None; M.R.Santhiago, None; N.Kara-Júnior, None.

Correspondence address: Rodrigo F. Espíndola. Praça das Hortências, 70 - Itu (SP) - 13301-689 Brazil -E-mail: rodrigo166@uol.com.br 


\section{METHODS}

This study was conducted according to ethical standards for clinical research and was approved by the University Hospital's research ethics committee/investigational review board. The observers who conducted the postoperative visual evaluations did not have access to the randomization code or information about the surgical procedures. Informed consent was obtained, and the study was conducted in adherence with the tenets of the Declaration of Helsinki.

All patients involved had bilateral sequential cataract surgery under similar preoperative conditions using the same phacoemulsification technique in both eyes. Only one experienced surgeon performed all surgeries.

Patients with visually significant bilateral cataract and no history of glaucoma were eligible for inclusion in the study. Exclusion criteria was any ocular disease, such as corneal opacities or irregularity, dry eye, amblyopia, anisometropia, retinal abnormalities, surgical complications, IOL tilt, previous or current use of medications known to cause color-vision deficiencies, or incomplete follow-up.

The patients were divided in two groups: first group compromised 25 patients (50 eyes). Each patient received a spherical foldable, 1-piece, hydrophobic acrylic IOL (Akreos Fit, Bausch \& Lomb, Inc.) in one eye and a 1-piece foldable, hydrophobic acrylic IOL (Akreos AO, Bausch \& Lomb, Inc.) with aspherical anterior and posterior surface in the fellow eye (aberration-free).

The second group enrolled 27 patients (54 eyes) with an ultraviolet and blue light filter IOL (AcrySof Natural SN60AT, Alcon) in one eye (yellow tinted), and an acrylic ultraviolet filter IOL (AcrySof SA60AT, Alcon) in the fellow eye (non-tinted).

Approximately 30 days after the first surgery, the second eye had cataract surgery with implantation of another IOL model. All patients and observers were masked about the IOL type implanted.

An envelope system was used to randomly assign all enrolled patients. Sequenced and sealed envelopes containing the first type of IOL (Akreos AO or Akreos Fit; SN60AT or MA60AC) were prepared before surgery. An unscrubbed observer in the operating room opened the envelopes and assigned each patient.

The individuals met the following inclusion criteria at two years postoperatively: visual acuity better than $0.3 \log$ MAR in both eyes, normal intraocular pressures, no evidence of posterior capsule opacity, and no signs of glaucoma.

The primary outcome measures of the study were contrast sensitivity and $B / Y$ perimetry values. The contralateral eye was used as control. Best-corrected visual acuity (BCVA) and distance uncorrected visual acuity (UCVA) were measured as well as $B / Y$ values. The visual acuity was measured at 100\% contrast using Early Treatment of Diabetic Retinopathy Study (ETDRS) charts (Precision Vision) under photopic conditions (target luminance 85 candelas $[\mathrm{cd}] / \mathrm{m}^{2}$ ) at $4.0 \mathrm{~m}$.

Contrast sensitivity was measured with VCTS 6000 (Vistech Consultants Incorporation, Dayton, OH, USA) with best spectacle correction under photopic $\left(85 \mathrm{~cd} / \mathrm{m}^{2}\right)$ and mesopic $\left(3 \mathrm{~cd} / \mathrm{m}^{2}\right)$ conditions. Light conditions were controlled with a luxometer (Gossen-Starlite, Nürnberg, Germany).

During visual field testing, optimal refractive correction was placed before the tested eye, and the fellow eye was occluded with an opaque eye patch. B/Y perimetry was performed (first in right eye) using the Humphrey Visual Field Analyzer (Carl Zeiss Meditec, USA). A full-threshold algorithm (central 24-2 full-threshold strategy) was used with a blue $(440 \mathrm{~nm})$ size $V\left(1.72^{\circ}\right)$ stimulus on a yellow background $(530 \mathrm{~nm})$, with maximum brightness of $100 \mathrm{~cd} / \mathrm{m}^{2}$. The measured levels were expressed in decibels $(\mathrm{dB})$ for all points.

Because the participants did not have previous experience with any visual field testing, they underwent two initials tests to minimize the learning curve. These tests were not included in the analysis.

Only visual field tests with reliable results were analyzed. A reliable test was defined as one with fixation losses of less than $25 \%$ and both false-positive and false-negative responses of less than $33 \%$.
Statistical analysis was conducted using the software SPSS version 15.0 (SPSS Inc., Chicago, IL, USA). Data were analyzed with the nonparametric Mann-Whitney $U$ test using a 5\% significance level and $80 \%$ power. The normality of the quantitative variables was verified using the Kolmogorov-Smirnov test. The level of statistical significance for such comparison was set a $p<.05$.

For our analysis, a sample size of at least 93 eyes per group allowed effect size of 0.85 (Wilcoxon test).

\section{RESULTS}

The first group enrolled 25 patients (12 men [48.0\%] and 13 women [52.0\%]). Mean age of the patients was $57.80 \pm 6.48$ years. The second group involved 27 patients (7 women [26.0\%] and 20 men [74.0\%]). Mean age was $68.5 \pm 3.84$ years. All patients completed 24 months of follow-up.

No eye had intraoperative complications. At two years after surgery, all lenses were well centered and there was no evidence of posterior capsule opacity or glaucoma. All subjects showed good reliability indices in $\mathrm{B} / \mathrm{Y}$ perimetry, thus, no test was excluded from the study.

The mean UCVA was $0.08 \pm 0.05$ in Akreos AO group and $0.09 \pm$ 0.06 in Akreos Fit group. There was no significant difference between the IOL groups for distance UCVA $(p=0.379)$. The mean BCVA was $0.01 \pm$ 0.10 in Akreos AO group and $0.02 \pm 0.09$ in Akreos FIT group ( $p=0.331$ ).

There was no statistical difference in UCVA and BCVA in SN60AT and MA60AC; the mean UCVA was $0.05 \pm 0.10$ in SN60AT group and $0.08 \pm 0.10$ in MA60AC group $(p=0.432)$. The mean BCVA was $0.01 \pm$ 0.10 in SN60AT group and $0.02 \pm 0.02$ in MA60AC group $(p=0.475)$.

Under photopic conditions, the aspherical IOL presented statistically better contrast sensitivity than spherical IOL only at 12 cycles per degree $(c p d)$ spatial frequency $(p=0.028)$. Under mesopic conditions, the Akreos AO IOL presented statistically better contrast sensitivity than Akreos Fit IOL at all spatial frequencies $(1.5,3,6,12$, and $18 \mathrm{cpd}$; $p=0.004, p=0.042, p=0.017, p=0.0017$, and $p=0.001$, respectively).

There were no between group significant differences (yellow tinted and non tinted $\mathrm{IOL}$ ) under photopic conditions (1.5 cpd, $3 \mathrm{cpd}, 6 \mathrm{cpd}$, $12 \mathrm{cpd}$, and $18 \mathrm{cpd} ; \mathrm{p}=0.798, \mathrm{p}=0.809, \mathrm{p}=0.738, \mathrm{p}=0.915$ and $\mathrm{p}=0.887$ respectively) or mesopic conditions $(1.5 \mathrm{cpd}, 3 \mathrm{cpd}, 6 \mathrm{cpd}, 12 \mathrm{cpd}$, and $18 \mathrm{cpd} ; \mathrm{p}=0.819, \mathrm{p}=0.736, \mathrm{p}=0.714, \mathrm{p}=0.819$ and $\mathrm{p}=0.917$ respectively).

Tables 1 and 2 shows mean defect (MD) and pattern standard deviation (PSD) distribution values in the first group (Akreos AO and Akreos Fit). There was no significant difference for either MD or PSD.

Tables 3 and 4 shows the B/Y values in the second group (SN60AT and MA60AC). There was no significant difference for either MD or PSD.

The mean test duration was similar in both groups, 230.5 seconds (213.5 - 266.0 seconds) with Akreos AO and 227.00 seconds (204.0 324.2 seconds) with Akreos Fit ( $p=0.213$ ). Eyes implanted with SN60AT had a test time of 232.4 seconds ( $210.2-268.4$ seconds) and 230.2 seconds (209.8 - 265.8 seconds) with MA60AC ( $p=0.238)$.

\section{DISCUSSION}

In the past 10 years the technique used for cataract surgery has improved ${ }^{(8)}$. Recent advances in wavefront technology have enabled measurements that describe aberrations of both the cornea ${ }^{(9)}$ and the

Table 1. Mean deviation (MD) of blue-on-yellow perimetry in eyes implanted with Akreos AO and Akreos Fit

\begin{tabular}{lcc}
\hline Value & $\begin{array}{c}\text { Akreos AO } \\
(\mathbf{d B})\end{array}$ & $\begin{array}{c}\text { Akreos Fit } \\
(\mathbf{d B})\end{array}$ \\
\hline Mean & -2.40 & -4.70 \\
Minimum & -5.07 & -6.09 \\
Maximum & -1.32 & -1.00 \\
\hline
\end{tabular}

$d B=$ decibels; $P=0.07$. 
Table 2. Pattern standard deviation (PSD) of blue-on-yellow perimetry in eyes implanted with Akreos AO and Akreos Fit

\begin{tabular}{lcc}
\hline Value & $\begin{array}{c}\text { Akreos AO } \\
(\mathbf{d B})\end{array}$ & $\begin{array}{c}\text { Akreos Fit } \\
\text { (dB) }\end{array}$ \\
\hline Mean & 3.30 & 3.80 \\
Minimum & 2.78 & 3.20 \\
Maximum & 4.72 & 5.10 \\
\hline
\end{tabular}

$\mathrm{dB}=$ decibels; $\mathrm{P}=0.13$

Table 3. Mean deviation (MD) of blue-on-yellow perimetry in eyes implanted with SN60AT and MA60AC

\begin{tabular}{lcc}
\hline Value & $\begin{array}{c}\text { MA60AC } \\
(\mathbf{d B})\end{array}$ & $\begin{array}{c}\text { SN60AT } \\
(\mathbf{d B})\end{array}$ \\
\hline Mean & -3.68 & -5.62 \\
Minimum & -21.70 & -22.67 \\
Maximum & 6.15 & 4.65 \\
\hline
\end{tabular}

$d B=$ decibels; $P=0.27$

Table 4. Pattern standard deviation (PSD) of blue-on-yellow perimetry in eyes implanted with SN60AT and MA60AC

\begin{tabular}{lcc}
\hline Value & $\begin{array}{c}\text { MA60AC } \\
(\mathbf{d B})\end{array}$ & $\begin{array}{c}\text { N60AT } \\
(\mathbf{d B})\end{array}$ \\
\hline Mean & 3.04 & 2.52 \\
Minimum & 0.00 & 0.00 \\
Maximum & 8.00 & 5.49 \\
\hline
\end{tabular}

$\mathrm{dB}=$ decibels; $\mathrm{P}=0.42$

entire refractive system of the eye ${ }^{(10)}$. The selection of aspherical IOLs to compensate for corneal aberrations can improve pseudophakic visual quality ${ }^{(11)}$.

After cataract removal with $\mathrm{OL}$ implantation, the $\mathrm{IOL}$ itself might confound the findings of common diagnostic tests such as perimetry ${ }^{(12-14)}$. There are no reports on the effect of aspherical IOL on $\mathrm{B} / \mathrm{Y}$ perimetry to our knowledge. This contralateral eye study was conducted to analyze the theoretical benefits of aspherical IOL implantation in improve contrast sensitivity and its consequences in B/Y parameters. Blue-filter IOLs were also taken into account.

Under mesopic conditions, postoperative VCTS contrast sensitivity testing showed significant differences between the 2 groups (aspherical and spherical IOLs) at all spatial frequencies, indicating that Akreos AO performed better than Akreos Fit in larger pupil sizes. However, under photopic conditions, the Akreos AO IOL performed better than Akreos Fit only at $12 \mathrm{cpd}$. Others studies confirms this findings ${ }^{(9,12)}$. Despite this improvement in contrast sensitivity, no changes in pattern standard deviation (PSD) or mean deviation (MD) were found comparing aspherical and spherical IOL.

Benefits of blue-filter IOLs that have been suggested include protection against retinal damage due to blue light, with a possible role in preventing the development or exacerbation of age-related macular degeneration. In addition, by blocking blue light, the optical chromatic aberration is reduced. Improvement in contrast sensitivity, reduced glare under photopic and mesopic conditions and reduction in disturbance of blue color vision are also expected. These changes could confound the interpretation of the glaucomatous visual field ${ }^{(15-20)}$.

In our study, no statistically difference was found in contrast sensitivity comparing yellow tinted and clear IOLs. Even with a shorter follow-up, most previous studies found no detrimental effect of blue light-filtering IOLs on photopic or mesopic contrast sensitivity or on color vision between eyes with blue light-filtering IOLs and eyes with UV light-filtering $1 \mathrm{OL} \mathrm{s}^{(21,22)}$

Castro et al. ${ }^{(23)}$, using a blue light spectrum filter (simulating an AcriSof Natural IOL) found statistically significant reductions in MD and foveal threshold on SWAP, but not in SAP examinations. However, this study was not conducted for patients with cataract (young patients). Our study did not confirm these results. A previous study by Jang et al. ${ }^{(24)}$, had similar findings to the results of Castro et al.

Another study on the influence of yellow IOL on SWAP, concluded that yellow IOLs did not affect SWAP results ${ }^{(25)}$, which is in agreement with our results. Ueda et al. ${ }^{(26)}$, also reported that no significant differences were observed between patients with yellow-tinted and clear IOLs for FDT perimetry results. They suggested that when interpreting the results of perimetry, the effect of cataract should be considered but that of IOL color does not need consideration.

Some studies described a better ${ }^{(26,27)}$ or worse ${ }^{(28,29)}$ performance of blue-light- filtering IOLs. The majority of the studies, however, did not find any statistically significant differences in comparison with UV-filtering $1 \mathrm{OL}^{(30-32)}$.

In this study, no significant difference for either MD or PSD was found between IOLs, although, the Akreos AO group demonstrated better values (Table 1 and 2). In spite of no scientific agreement exists as to whether removing aberrations from the visual system may result in a better retinal image, it is also apparent that zero spherical aberration does not automatically provide best visual performance.

This study has limitations that included the absence of preoperative $B / Y$ perimetry data, the small number of cases, and the absence of concurrent standard automated perimetry. A larger number of cases, (proximally 100 cases in each group), could make a difference in the findings between each group, or confirm the result seen in this study.

The fact that this study makes a contralateral comparison minimizes intraindividual factors that could interfere with contrast sensitivity and the results of $B / Y$ perimetry. Different IOLs from the same manufacturer were used to minimize bias.

\section{CONCLUSION}

In summary, aspherical IOL showed better performance in the contrast sensitivity test under mesopic conditions compared with the spherical IOL. Blue-yellow perimetry did not appear to be affected by aspherical or yellow tinted IOL. Further studies with a larger sample size are necessary.

\section{REFERENCES}

1. Sample PA, Johnson CA, Haegerstrom-Portnoy G, Adams AJ. Optimum parameters for short-wavelength automated perimetry. J Glaucoma. 1996;5(6):375-83. Comment in: J Glaucoma. 2000;9(1):3-4.

2. Johnson CA. Diagnostic value of short-wavelength automated perimetry. Curr Opin Ophthalmol. 1996:7(2):54-8.

3. Sample PA, Weinreb RN. Progressive color visual field loss in glaucoma. Invest Ophthalmol Vis Sci. 1992;33(6):2068-71.

4. Sample PA, Taylor JD, Martinez GA, Lusky M, Weinreb RN. Short-wave-length color visual fields in glaucoma suspects at risk. Am J Ophthalmol, 1993;115(2):225-33.

5. Wild JM, Moss ID, Whitaker D, O'Neill EC. The statistical interpretation of blue-on-yellow visual field loss. Invest Ophthalmol Vis Sci. 1995;36(7):1398-410.

6. Tafreshi A, Sample PA, Liebmann JM, Girkin CA, Zagwill LM, Weinreb RN, et al. Visua function-specific perimetry to identify glaucomatous visual loss using three different definitions of visual field abnormality. Invest Ophthalmol Vis Sci. 2009:50(3):1234-40.

7. Carrillo MM, Artes PH, Nicolela MT, LeBlanc RP, Chauhan BC. Effect of cataract extraction on the visual fields of patients with glaucoma. Arch Ophthalmol. 2005; 123(7):929-32

8. Sirtoli MG, Santhiago MR, Parede TR, Espíndola RF, Carvalho RS, Kara-Junior N. Phacoemulsification versus extracapsular extraction: governmental costs. Clinics. 2010;65(4): 357-61.

9. Guirao A, Redondo M, Artal P. Optical aberrations of the human cornea as a function of age. J Opt Soc Am A Opt Image Sci Vis. 2000;17(10):1697-702. 
10. Artal P, Berrio E, Guirao A, Piers P. Contribution of the cornea and internal surfaces to the change of ocular aberrations with age. J Opt Soc Am A Opt Image Sci Vis. 2002 19(1):137-43.

11. Kara-Junior N, Santhiago MR. Lentes asféricas: avaliação da indicação clínica e das opções de lentes. Rev Bras Oftalmol. 2009;68(4):195-6.

12. Santhiago MR, Netto MV, Barreto J Jr, Gomes BA, Mukai A, Guermandi AP, et al. Wavefront analysis, contrast sensitivity, and depth of focus after cataract surgery with aspherical intraocular lens implantation. Am J Ophtalmol. 2010;149(3):383-9.

13. Caporossi A, Casprini F, Tosi GM, Baiocchi S. Preliminary results of cataract extraction with implantation of a single-piece AcrySof intraocular lens. J Cataract Refract Surg. 2002;28(4):652-5.

14. Kim YY, Kim JS, Shin DH, Kim C, Jung HR. Effect of cataract extraction on blue-on-yellow visual field. Am J Ophthalmol. 2001;132(2):217-20.

15. Kook MS, Yang SJ, Kim S, Chung J, Kim ST, Tchah H. Effect of cataract extraction on frequency doubling technology perimetry. Am J Ophthalmol. 2004;138(1):85-90.

16. Moss ID, Wild JM, Whitaker DJ. The influence of age-related cataract on blue-on-yelIow perimetry. Invest Ophthalmol Vis Sci. 1995;36(5):764-73.

17. Henderson BA, Grimes KJ. Blue-blocking IOLs: a complete review of the literature Surv Ophthalmol. 2010;55(3):284-9.

18. Cuthbertson FM, Peirson SN, Wulff K, Foster RG, Downes SM. Blue light-filtering intraocular lenses: review of potential benefits and side effects. J Cataract Refract Surg. 2009;35(7): 1281-97. Comment in: J Cataract Refract Surg. 2009;35(11):2032; author reply 2032.

19. Mainster MA. Violet and blue light blocking intraocular lenses: photoprotection versus photoreception. Br J Ophthalmol. 2006;90(6):784-92.

20. Rodríguez-Galietero A, Montés-Micó R, Muñoz G, Albarrán-Diego C. Comparison of contrast sensitivity and color discrimination after clear and yellow intraocular lens implantation. J Cataract Refract Surg. 2005;31(9):1736-40.

21. Rodríguez-Galietero A, Montés-Micó R, Muñoz G, Albarrán-Diego C. Blue-light filtering intraocular lens in patients with diabetes: contrast sensitivity and chromatic discrimination. J Cataract Refract Surg. 2005;31(11):2088-92.
22. Hayashi K, Hayashi H. Visual function in patients with yellow tinted intraocular lenses compared with vision in patients with non-tinted intraocular lenses. $\mathrm{Br} J$ Ophthalmol. 2006;90(8):1019-23.

23. Castro LC, Souza CE, Soriano ES, Melo LA Jr, Paranhos A Jr. Influence of blue light spectrum filter on short-wavelength and standard automated perimetries. Arq Bras Oftalmol. 2006;69(5):725-9.

24. Jang SY, Ohn YH, Kim SW. Effect of yellow-tinted intraocular lenses on short-wavelength automated perimetry. Am J Ophthalmol. 2010;150(2):243-7. Comment in: Am J Ophthalmol. 2011;15(2):380; author reply 380-1.

25. Kara-Júnior N, Jardim JL, de Oliveira Leme E, Dall'Col M, Susanna R Jr. Effect of the AcrySof Natural intraocular lens on blue-yellow perimetry. J Cataract Refract Surg. 2006;32(8):1328-30.

26. Ueda T, Ota T, Yukawa E, Hara Y. Frequency doubling technology perimetry after clear and yellow intraocular lens implantation. Am J Ophthalmol. 2006;142(5):856-8.

27. Yuan Z, Reinach P, Yuan J. Contrast sensitivity and color vision with a yellow intraocular lens. Am J Ophthalmol. 2004;138(1):138-40.

28. Rodriguez-Galietero A, Montes-Mico R, Munoz G, Albarrán-Diego C. Blue-light filtering intraocular lens in patients with diabetes: contrast sensitivity and chromatic discrimination. J Cataract Refract Surg. 2005;31(11):2088-92.

29. Mainster M, Sparrow. How much blue-light should an IOL transmit? Br J Ophthalmol. 2003;87(12):1523-9. Comment in: Br J Ophthalmol. 2004;88(10):1353; author reply 1353.

30. Pierre A, Wittich W, Faubert J, Overbury O. Luminance contrast with clear and yellowtinted intraocular lenses. J Cataract Refract Surg. 2007;33(7):1248-52.

31. Landers J, Tan TH, Yen J, Liu H. Comparison of visual function following implantation of Acrisof Natural intraocular lenses with conventional intraocular lenses. Clin Experiment Ophthalmol. 2007;35(2):152-9.

32. Cionni RJ, Tasi JH. Color perception with AcriSof natural and AcriSof single-piece intraocular lenses under photopic and mesopic conditions. J Cataract Refract Surg. 2006;32(2):236-42. 